\title{
ANALIZA CEN W PRZYMUSOWYCH WYKUPACH AKCJI ORAZ W WEZWANIACH JE POPRZEDZAJACYCH NA GIEŁDZIE PAPIERÓW WARTOŚCIOWYCH W WARSZAWIE
}

\begin{abstract}
Streszczenie. Funkcjonowanie giełdy jako rynku regulowanego jest unormowane w przepisach prawnych. W większości przypadków te przepisy mają na celu ochronę nieprofesjonalnych uczestników obrotu, inwestorów indywidualnych czy mniejszościowych akcjonariuszy. Przykładem takich przepisów jest określenie minimalnej ceny, po jakiej dokonywany jest przymusowy wykup akcji. Przepis ten ma zapewnić akcjonariuszom mniejszościowym odpowiednią cenę w zamian za odkupywane akcje w warunkach, gdy ich pozycja stała się w zasadzie marginalna. Celem niniejszego opracowania jest analiza kształtowania się cen w przymusowych wykupach akcji na Giełdzie Papierów Wartościowych w Warszawie oraz w wezwaniach poprzedzających przymusowy wykup.
\end{abstract}

Słowa kluczowe: akcje, przymusowy wykup, rynek kapitałowy.

JEL: G100, G290, G340

\section{WPROWADZENIE}

Giełda jest rynkiem regulowanym przepisami prawnymi. W większości przypadków przepisy prawne mają na celu ochronę podmiotów cechujących się słabszą pozycją, np. nieprofesjonalnych uczestników obrotu, inwestorów indywidualnych czy mniejszościowych akcjonariuszy. Ciekawym przykładem regulacji są te dotyczące przymusowego wykupu akcji. Ich zadaniem jest ochrona interesów akcjonariuszy większościowych, ale nie tylko. Na przykład ustawa określa minimalną cenę, po jakiej jest dokonywany przymusowy wykup. Przepis ten ma zapewnić akcjonariuszom mniejszościowym odpowiednią cenę w zamian za odkupywane akcje w warunkach, gdy ich pozycja stała się w zasadzie marginalna.

Problematyka przymusowego wykupu akcji jest w dzisiejszych czasach zagadnieniem nader aktualnym. W dobie fuzji, przejęć oraz nasilających się trendów konsolidacyjnych w poszczególnych branżach, kwestia sposobów łączenia się i przejmowania przedsiębiorstw stale wzbudza zainteresowanie.

* Uniwersytet Marii Curie-Skłodowskiej, Wydział Ekonomiczny, Zakład Rynków Finansowych, katarzyna.krolik-koltunik@umcs.pl 
Dotychczas przeprowadzane badania i analizy na rynku polskim skupiały się głównie na aspektach prawnych przymusowego wykupu akcji. Nowak dokonała porównania przymusowego wykupu akcji (squeeze-out) i przymusowego odkupu akcji (reverse squeeze-out) w odniesieniu do spółek niepublicznych, czyli nienotowanych na rynku regulowanym (Nowak 2006: 25-27). Z kolei Pinior i Wyrzykowski opisują przepisy prawne regulujące przymusowy wykup i odkup akcji w spółkach zarówno niepublicznych, jak i publicznych (Pinior, Wyrzykowski 2008: 9). Niektóre publikacje skupiają się zaś na analizie polskich rozwiązań prawnych w porównaniu z przepisami obowiązującymi w innych krajach Unii Europejskiej (Wyszogrodzka 2006: 51-62, Puchalski 2015: 45-53). W odniesieniu do spółek publicznych opisana została procedura przeprowadzania przymusowego wykupu akcji (Walasek 2008: 53-58). Omówione zostały także zasady ustalania ceny w przymusowym wykupie akcji dotyczące spółek publicznych (Woźniak 2014: 50-54). Problemem ustalenia ceny w sytuacji przymusowego wykupu akcji zajęli się również Zarzecki i Grudziński (Zarzecki, Grudziński 2011: 661-676), lecz skupiają się oni na zagadnieniu ustalania wartości godziwej stosowanej przede wszystkim w odniesieniu do spółkę niepublicznych, gdzie utrudnione jest określenie ceny rynkowej ${ }^{1}$.

Zagraniczne opracowania naukowe także skupiają się głównie na stronie prawnej przymusowego wykupu akcji w poszczególnych krajach, np. w Stanach Zjednoczonych (Regner 2006: 158-160), w Kanadzie (Nicholls 2006: 407-427), w Japonii (Fujiwara, Tsujikawa 2008: 27-32), w Niemczech (Horbach, Koch 2006: 24-25), w Austrii (Birkner, Hasenauer 2007: 13-15) czy we Francji (Assant, Kanovitch 2005: 25-27, Cafritz 2005: 17-19). Część opracowań dotyczy wprowadzania w ramach dostosowań uregulowań prawnych do dyrektywy unijnej squeeze-out- $u$ w krajach Unii Europejskiej, w których to rozwiązania wcześniej nie funkcjonowało ${ }^{2}$, np. na Węgrzech (Nanyista, Hetényi 2007: 37-39), na Słowacji (Siska, Tadlánková 2007: 75-77), w Czechach (Marc, Lisková 2006: 70-71), w Grecji (Rampos 2007: 30-31) czy na Łotwie (Gencs 2004: 52-54). Najbardziej kompleksowe jest opracowanie Van der Elsta i Van den Steen (Van der Elst, Van den Steen 2009: 391-439), w którym autorzy dokonują porównania rozwiązań prawnych w zakresie przymusowego wykupu i odkupu akcji w pięciu krajach UE, tj. w Belgii, Francji, Niemczech, Holandii i Wielkiej Brytanii.

${ }^{1} \mathrm{~W}$ spółkach niepublicznych, które nie są notowane na rynku regulowanym np. na giełdzie, do ustalenia aktualnej ceny akcji są stosowane różne metody. W przypadku spółek publicznych, notowanych na giełdzie, określenie bieżącej ceny rynkowej odbywa się na bieżąco przez cały czas, co jest efektem ciągłego dopasowywania się popytu i podaży. Wartość godziwa jest wykorzystywana w odniesieniu do spółek publicznych, tylko w sytuacji, gdy niemożliwe jest ustalenie właściwej ceny rynkowej.

${ }^{2}$ Polska była jednym z takich krajów. Obowiązujące przepisy dotyczyły tylko spółek niepublicznych, w związku z wprowadzaniem dyrektywy przymusowy wykup akcji został umożliwiony w spółkach notowanych na giełdzie. 
Celem niniejszego opracowania jest analiza kształtowania się cen w wezwaniach przymusowego wykupu akcji na Giełdzie Papierów Wartościowych w Warszawie i znalezienie odpowiedzi na pytanie, czy dominujący akcjonariusz (bądź akcjonariusze), dokonując przymusowego wykupu akcji, byli skłonni zapłacić drobnym akcjonariuszom więcej niż minimalna cena określona w przepisach prawnych. Dodatkowo przeanalizowano ceny w wezwaniach poprzedzających przymusowy wykup akcji, stawiając analogiczne pytanie, czy drobni akcjonariusze otrzymali propozycje ceny wyższej niż minimalna cena wymagana przepisami prawnymi. Zagadnienie to było dotychczas pomijanie w opracowaniach naukowych. Tak postawione cele zaowocowały postawieniem dwóch hipotez badawczych. Hipoteza pierwsza: Podmioty przejmujące spółkę płacą inwestorom w przymusowym wykupie akcji więcej niż minimalna cena określona w przepisach prawnych. Hipoteza druga: Podmioty przejmujące spółkę płacą inwestorom w wezwaniu poprzedzającym przymusowy wykup akcji więcej niż minimalna cena określona w przepisach prawnych. Pozytywna weryfikacja hipotez będzie świadczyła, o tym, że inwestorzy, którzy zostali w zasadzie zmuszeni do wyjścia ze spółki, dostali cenę przewyższającą minimalną cenę zapisaną przez ustawodawcę.

\section{ISTOTA PRZYMUSOWEGO WYKUPU AKCJI}

W przepisach prawnych istnieją dwa rodzaje przymusowych wykupów bądź odkupów akcji. Pierwsza możliwość to przymusowy wykup akcji od akcjonariuszy mniejszościowych. Polega on na tym, że akcjonariusz większościowy, po osiągnięciu określonego udziału w kapitale zakładowym lub ogólnej liczbie głosów, może żądać, aby akcjonariusze mniejszościowi sprzedali mu swoje akcje. Tę procedurę zwykle określa się mianem przymusowego wykupu akcji lub stosuje się angielskie określenie squeeze-out, tłumaczone jako „wyciskanie” akcjonariuszy mniejszościowych. Druga możliwość to przymusowy odkup akcji, który polega na tym, że to akcjonariusze mniejszościowi mają prawo żądać, aby akcjonariusz większościowy odkupił do nich akcje. Ta procedura jest określana również jako prawo przymusowego wykupu lub stosuje się angielskie określenia reverse squeeze-out, buy-out right lub sell-out right. ${ }^{3}$

Powodem, dla którego większościowi akcjonariusze decydują się na przymusowy wykup akcji, jest chęć uwolnienia się od kosztów wynikających z funkcjonowania w spółce drobnych akcjonariuszy (Rusek, Hajdecki 2008: 75). Wykupienie udziałów od akcjonariuszy mniejszościowych wpływa na przyspieszenie procesów decyzyjnych i usprawnienie zarządzania spółką. Możliwe jest podejmowanie strategicznych decyzji charakteryzujących się podwyższonym ryzykiem, które

${ }^{3}$ Dokładne porównanie przymusowego wykupu i odkupu akcji w spółkach niepublicznych można znaleźć w opracowaniu D. Nowak (Nowak 2006: 25-27). 
mogłyby spowodować sprzeciw ze strony mniejszościowych akcjonariuszy. Dzięki przymusowemu wykupowi akcji spółka chroni się przed zachowaniami tzw. drobnego akcjonariatu określanymi jako „szantaż korporacyjny”, czyli sytuacjami, kiedy prawa mniejszości są nadużywane, np. drobni akcjonariusze konsekwentnie zaskarżają uchwały w celu utrudniania zarządzania spółką. Spółce, w której nie występują drobni akcjonariusze, łatwiej jest też pozyskać inwestora strategicznego (Pinior, Wyrzykowski 2008: 9). W przypadku spółek publicznych przeprowadzenie przymusowego wykupu akcji jest najczęściej jednym z etapów w procesie wycofywania spółki z obrotu giełdowego i zniesienia dematerializacji akcji.

\section{BADANIE}

\subsection{Zakres badań}

Przepisy prawne regulujące przymusowy wykup akcji w spółkach publicznych znalazły się w ustawie z dnia 29 lipca 2005 r. o ofercie publicznej i warunkach wprowadzania instrumentów finansowych do zorganizowanego systemu obrotu oraz o spółkach publicznych (Dz.U. 2005 nr 184 poz. 1539 z późn. zm.), zwanej dalej Ustawą o ofercie publicznej. Przepisy te zaczęły obowiązywać w 2005 roku, gdy weszła w życie ustawa. Wcześniej przymusowy wykup akcji mógł być przeprowadzony tylko w spółkach niepublicznych. Kodeks spółek handlowych, który reguluje tę kwestię, stanowi, że zawartych tam przepisów nie stosuje się do spółek publicznych.

Tabela 1 przedstawia ilościowe zestawienie przymusowych wykupów akcji od 2005 roku, czyli od momentu wprowadzenia w życie stosownych przepisów, do końca 2015 roku. W tym okresie przeprowadzono 48 przymusowych wykupów akcji. Rekordowy pod tym względem był rok 2010, gdy przeprowadzono 10 squeeze-outów. W ostatnich latach przymusowe wykupy akcji znów pojawiają się coraz częściej, w latach 2014-2015 przeprowadzono ich w sumie 13.

Tabela 1

Ilość przymusowych wykupów akcji ogłoszonych w latach 2005-2015

\begin{tabular}{|c|c|}
\hline Rok & Liczba ogłoszonych przymusowych wykupów akcji \\
\hline 1 & 2 \\
\hline 2005 & 0 \\
\hline 2006 & 7 \\
\hline 2007 & 5 \\
\hline 2008 & 3 \\
\hline
\end{tabular}




\begin{tabular}{|c|c|}
\hline 1 & 2 \\
\hline 2009 & 2 \\
\hline 2010 & 10 \\
\hline 2011 & 1 \\
\hline 2012 & 5 \\
\hline 2013 & 2 \\
\hline 2014 & 6 \\
\hline 2015 & 7 \\
\hline
\end{tabular}

Źródło: Opracowanie własne na podstawie bazy danych GPW.

Badaniem objęto przymusowe wykupy akcji przeprowadzane na rynku głównym Giełdy Papierów Wartościowych w Warszawie w latach 2010-2015. Okres badawczy został zawężony z uwagi na trudności w dostępie do szczegółowych danych dotyczących przymusowych wykupów akcji przeprowadzanych na giełdzie w latach 2005-2009. Dane wykorzystane w badaniach zostały pozyskane z serwisu Giełdy Papierów Wartościowych w Warszawie - GPWInfoStrefa. Przeanalizowane zostały komunikaty dotyczące wezwań na sprzedaż akcji w drodze przymusowego wykupu oraz wezwań poprzedzających przymusowy wykup. Utworzone w ten sposób zestawienie danych posłużyło do przeprowadzenia dalszych analiz.

$\mathrm{W}$ analizowanym okresie przeprowadzono 31 przymusowych wykupów. Szczegółowe informacje o tych przypadkach zamieszczone zostały w tabeli 2 . Umieszczono tam dane o spółkach, których akcje były objęte przymusowym wykupem, podmiocie lub podmiotach dokonujących przymusowego wykupu akcji, procentowym udziale głównych akcjonariuszy w ogólnej liczbie głosów (przymusowy wykup jest możliwy, jeśli wzywający przekroczy próg $90 \%$ ogólnej liczby głosów w spółce), a także o datach ogłoszenia przymusowego wykupu oraz ostatniego notowania akcji spółki na giełdzie. W prawie wszystkich analizowanych przypadkach przymusowy wykup akcji poprzedzał wycofanie spółki z obrotu giełdowego. Wyjątkiem był tylko bank BGŻ, który po połączeniu z bankiem BNP Paribas nadal jest notowany na Giełdzie Papierów Wartościowych w Warszawie. Zaś spółki, względem których przymusowy wykup został ogłoszony w ostatnim kwartale 2015 roku, na początku 2016 roku wciąż nie zostały formalnie wykluczone z obrotu giełdowego. W dalszym ciągu są notowane, jednak obrót ich akcjami został zawieszony (nie jest możliwe zawarcie transakcji kupna-sprzedaży $)^{4}$. Prawdopodobnie kwestią czasu jest wykluczenie tych spółek z obrotu giełdowego.

${ }^{4}$ Giełda Papierów Wartościowych zawiesza obrót akcjami danej spółki w momencie ogłoszenia przymusowego wykupu akcji. 
Tabela 2

Przymusowe wykupy akcji ogłoszone w latach 2010-2015

\begin{tabular}{|c|c|c|c|c|}
\hline Spółka & $\begin{array}{l}\text { Podmiot ogłasza- } \\
\text { jący wezwanie } \\
\text { (Główny akcjo- } \\
\text { nariusz) }\end{array}$ & $\begin{array}{c}\text { Proc. udział } \\
\text { głównego akcjo- } \\
\text { nariusza }\end{array}$ & $\begin{array}{l}\text { Data wezwania } \\
\text { squeeze-out }\end{array}$ & $\begin{array}{c}\text { Data ostatniego } \\
\text { notowania }\end{array}$ \\
\hline 1 & 2 & 3 & 4 & 5 \\
\hline $\begin{array}{l}\text { PANI TERESA- } \\
\text {-MEDICA }\end{array}$ & $\begin{array}{c}\text { Sigvaris Holding } \\
\text { AG }\end{array}$ & 96,39 & 28.12 .2015 & nd. \\
\hline Infovide-Matrix & Asseco Poland & 97,91 & 21.12 .2015 & nd. \\
\hline VARIANT & $\begin{array}{l}\text { PREDICTO i } \\
\text { ESTATER }\end{array}$ & 90,12 & 30.11 .2015 & nd. \\
\hline KOFOLA & $\begin{array}{c}\text { Kofola ČeskoS- } \\
\text { lovensko }\end{array}$ & 99,8 & 20.11 .2015 & nd. \\
\hline ECARD & $\begin{array}{l}\text { MCI.PrivateVen- } \\
\text { tures FIZ i TUW } \\
\text { SKOK }\end{array}$ & 90,33 & 19.10 .2015 & nd. \\
\hline TVN & $\begin{array}{c}\text { Southbank Me- } \\
\text { dia Limited }\end{array}$ & 98,76 & 23.09 .2015 & 05.10 .2015 \\
\hline Bipromet & KGHM & 91,23 & 22.04 .2015 & 25.05 .2015 \\
\hline BGŻ & $\begin{array}{l}\text { BNP Paribas i } \\
\text { Rabobank }\end{array}$ & 98,98 & 23.12 .2014 & nd. \\
\hline ZPC Mieszko & $\begin{array}{l}\text { Bisantio Invest- } \\
\text { ments }\end{array}$ & 91,01 & 26.11 .2014 & 30.12 .2014 \\
\hline Bakalland & $\begin{array}{c}\text { Innova Phoenix } \\
\text { i inni }\end{array}$ & 91,1 & 12.11 .2014 & 04.02 .2015 \\
\hline Nordea Bank & PKO BP & 99,82 & 06.05 .2014 & 28.10 .2014 \\
\hline $\begin{array}{c}\text { Armatura Kra- } \\
\text { ków }\end{array}$ & $\begin{array}{l}\text { PZU FIZ Akty- } \\
\text { wów Niepublicz- } \\
\text { nych BIS } 2\end{array}$ & 92,75 & 16.01 .2014 & 07.03 .2014 \\
\hline Barlinek & Michał Sołowow & 94,34 & 08.01 .2014 & 20.03 .2014 \\
\hline POL-AQUA & DRAGADOS & 96,18 & 18.10 .2013 & 09.12 .2013 \\
\hline Zelmer & $\mathrm{BSH}$ & 97,78 & 12.04 .2013 & 10.06 .2013 \\
\hline POLLENA-EWA & TZMO & 93,56 & 08.11 .2012 & 18.02 .2013 \\
\hline Centrum Klima & LINDAB & 97,3 & 01.08 .2012 & 29.11.2012 \\
\hline TU Europa & $\begin{array}{c}\text { Talanx Inter- } \\
\text { national, Meij } \\
\text { Yasuda, Getin } \\
\text { Holding }\end{array}$ & 94,52 & 19.07.2012 & 22.10 .2012 \\
\hline Mondi Świecie & $\begin{array}{l}\text { Mondi Interna- } \\
\text { tional i Framondi }\end{array}$ & 93,19 & 14.05 .2012 & 06.08 .2012 \\
\hline
\end{tabular}




\begin{tabular}{|c|c|c|c|c|}
\hline 1 & 2 & 3 & 4 & 5 \\
\hline Elstar Oil & $\begin{array}{c}\text { Archer Daniels } \\
\text { Miland }\end{array}$ & 97,74 & 07.12 .2012 & 09.03 .2012 \\
\hline $\begin{array}{c}\text { Multimedia } \\
\text { Polska }\end{array}$ & $\begin{array}{c}\text { Lubotech Limi- } \\
\text { ted i inni }\end{array}$ & 90,57 & 23.08 .2011 & 07.11 .2011 \\
\hline Ruch & Lurena & 90,03 & 20.10 .2010 & 14.01 .2011 \\
\hline WOLA INFO & Devoteam & 93,23 & 08.10 .2010 & 18.03 .2011 \\
\hline DZ Bank Polska & DZ Bank & 99,87 & 23.09 .2010 & 11.01 .2011 \\
\hline Nepentes & Sanofi-Aventis & 99,7 & 13.09 .2010 & 30.12 .2010 \\
\hline Kable & NKT Cables & 90,61 & 30.08 .2010 & 22.12 .2010 \\
\hline Teta & Unit4 & 93,01 & 30.07 .2010 & 25.08 .2010 \\
\hline WSIP & $\begin{array}{c}\text { Pahoa Invest- } \\
\text { ments }\end{array}$ & 90,42 & 30.04 .2010 & 01.09 .2010 \\
\hline Optopol Techno- & $\begin{array}{c}\text { Canon Inc. oraz } \\
\text { Adam Bogdani }\end{array}$ & 99,35 & 23.03 .2010 & 29.06 .2010 \\
\hline HTL-Strefa & $\begin{array}{c}\text { Terantium In- } \\
\text { vestment }\end{array}$ & 97,68 & 22.02 .2010 & 27.09 .2010 \\
\hline Bankier.pl & MIH Allegro & 91,16 & 29.01 .2010 & 24.05 .2010 \\
\hline
\end{tabular}

Objaśnienia do tabeli: nd. - nie dotyczy.

Źródło: Opracowanie własne na podstawie bazy danych GPW.

\subsection{Metodyka badań}

Cena, po jakiej jest dokonywany przymusowy wykup akcji, jest ustalana zgodnie z art. 79, ust. 1-3 ustawy o ofercie publicznej. Musi być ona jednolita dla wszystkich akcji. Wspomniany przepis wskazuje trzy takie ceny.

Po pierwsze, w przypadku spółek notowanych na rynku regulowanym, ustalona cena nie może być niższa niż średnia cena rynkowa z okresu 6 miesięcy poprzedzających wezwanie lub krótszego okresu, jeśli spółka była notowana krócej niż pół roku. W sytuacjach, gdy niemożliwe byłoby ustalenie ceny w ww. sposób lub w przypadku spółek, wobec których toczy się postępowanie układowe lub upadłościowe, ustalona cena nie może być niższa od wartości godziwej.

Po drugie, cena akcji zaproponowana w przymusowym wykupie nie może być niższa od najwyższej ceny, jaką podmiot wzywający do sprzedaży zapłacił za te akcje w ciągu ostatnich 12 miesięcy przed wezwaniem oraz nie niższa od najwyższej wartości rzeczy lub praw, które podmiot wydał w zamian za akcje będące przedmiotem wezwania w okresie ostatnich 12 miesięcy.

Po trzecie, proponowana cena nie może być również niższa od średniej ceny rynkowej z okresu 3 miesięcy obrotu na rynku regulowanym poprzedzających wezwanie.

Dodatkowo art. 82, ust. 2a ustawy o ofercie publicznej podaje czwarty przypadek. Jeśli osiągniecie lub przekroczenie progu 90\% ogólnej liczby głosów 
nastąpiło w drodze wezwania na sprzedaż wszystkich pozostałych akcji, to cena wykupu nie może być niższa od ceny proponowanej w tym wezwaniu.

Pierwsze trzy wymienione ceny są również cenami minimalnymi w wezwaniach na sprzedaż $100 \%$ akcji spółki, które to zazwyczaj poprzedzają przymusowy wykup akcji.

Jako, że celem przeprowadzanych badań było sprawdzenie, czy akcjonariusz większościowy dokonujący przymusowego wykupu akcji, był skłonny zapłacić drobnym akcjonariuszom więcej niż cena minimalna określona w przepisach prawnych, $\mathrm{w}$ toku badań porównane zostaną ceny ogłoszone w wezwaniach z minimalnymi cenami wymaganymi przez przepisy prawne. Zarówno hipoteza pierwsza, jak i druga zostaną pozytywnie zweryfikowane, jeśli w większości badanych przypadków cena płacona w wezwaniu będzie wyższa niż minimalna cena określona w przepisach prawnych. Jeśli okaże się, że cena w wezwaniu przewyższała ustawowo określoną cenę minimalną, to dodatkowo przeanalizowana zostanie wielkość tej różnicy przy wykorzystaniu podstawowych miar rozkładu takich jak: minimum, maksimum, średnia, odchylenie standardowe, mediana, pierwszy i trzeci kwartyl oraz współczynnik skośności.

\subsection{Wyniki badań}

Tabela 3 przedstawia zestawienie cen w analizowanych przypadkach przymusowych wykupów akcji oraz cen minimalnych określonych w ustawie o ofercie publicznej. W tabeli została pominięta cena związana z transakcjami, w których podmiot dokonujący wykupu w okresie 12 miesięcy poprzedzających wezwanie nabywał akcje w zamian za świadczenia niepieniężne, gdyż tylko $\mathrm{w}$ jednym $\mathrm{z}$ analizowanych przypadków doszło do takiego zdarzenia ${ }^{5}$. Średnie ceny rynkowe z okresu sześciu i trzech miesięcy poprzedzających wezwanie (czyli cena 2 i 3) wylicza się jako średnią arytmetyczną ze średnich dziennych cen ważonych wolumenem obrotu.

Tabela 3

Ceny (w zł) w wezwaniach przymusowego wykupu akcji w latach 2010-2015

\begin{tabular}{|c|c|c|c|c|c|c|}
\hline Spółka & $\begin{array}{c}\text { Data } \\
\text { wezwania }\end{array}$ & Cena 1 & Cena 2 & Cena 3 & Cena 4 & Cena 5 \\
\hline 1 & 2 & 3 & 4 & 5 & 6 & 7 \\
\hline $\begin{array}{c}\text { PANI } \\
\text { TERESA- } \\
\text {-MEDICA }\end{array}$ & 28.12 .2015 & 15,45 & 15,05 & 15,22 & 15,45 & 15,45 \\
\hline
\end{tabular}

${ }^{5}$ Miało ono miejsce z przypadku spółki KOFOLA, cena akcji w transakcjach została wyceniona na $45,33 \mathrm{zł}$. 


\begin{tabular}{|c|c|c|c|c|c|c|}
\hline 1 & 2 & 3 & 4 & 5 & 6 & 7 \\
\hline $\begin{array}{l}\text { Infovide- } \\
\text {-Matrix }\end{array}$ & 21.12 .2015 & 6,01 & 4,35 & 5,76 & 6,01 & 6,01 \\
\hline VARIANT & 30.11 .2015 & 1,67 & 1,65 & 1,65 & nd. & nd. \\
\hline KOFOLA & 20.11 .2015 & 57 & 43,97 & 55,25 & 57 & nd. \\
\hline ECARD & 19.10 .2015 & 4 & 2,91 & 3,58 & 4 & nd. \\
\hline TVN & 23.09.2015 & 20 & 18,65 & 19,71 & 20 & 20 \\
\hline Bipromet & 22.04 .2015 & 6,29 & 5,29 & 5,98 & 6,29 & 6,29 \\
\hline BGŻ & 23.12 .2014 & 80,47 & 73,07 & 73,73 & 80,47 & 80,47 \\
\hline $\begin{array}{c}\text { ZPC } \\
\text { Mieszko }\end{array}$ & 26.11 .2014 & 3,99 & 3,64 & 3,79 & 3,99 & 3,99 \\
\hline Bakalland & 12.11 .2014 & 2,80 & 2,56 & 2,77 & 2,80 & 2,80 \\
\hline $\begin{array}{c}\text { Nordea } \\
\text { Bank }\end{array}$ & 06.05 .2014 & 47,99 & 46,85 & 47,23 & 47,99 & 47,99 \\
\hline $\begin{array}{l}\text { Armatura } \\
\text { Kraków }\end{array}$ & 16.01 .2014 & 1,70 & b.d. & b.d. & 1,70 & 1,70 \\
\hline Barlinek & 08.01 .2014 & 1,30 & 1,25 & 1,28 & 1,30 & 1,30 \\
\hline $\begin{array}{l}\text { POL- } \\
\text {-AQUA }\end{array}$ & 18.10 .2013 & 3,92 & 3,47 & 3,83 & 3,92 & 3,92 \\
\hline Zelmer & 12.04 .2013 & 40,00 & 37,84 & 39,30 & 40,00 & 40,00 \\
\hline $\begin{array}{l}\text { POLLE- } \\
\text { NA-EWA }\end{array}$ & 08.11 .2012 & 9,90 & 9,57 & 9,71 & 9,90 & 9,90 \\
\hline $\begin{array}{c}\text { Centrum } \\
\text { Klima }\end{array}$ & 01.08 .2012 & 14,50 & 12,81 & 14,28 & 14,50 & 14,50 \\
\hline TU Europa & 19.07.2012 & 193,00 & 189,25 & 189,89 & 193,00 & 193,00 \\
\hline $\begin{array}{c}\text { Mondi } \\
\text { Świecie }\end{array}$ & 14.05 .2012 & 72,00 & 65,11 & 70,91 & 72,00 & 72,00 \\
\hline Elstar Oil & 07.12 .2012 & 6,50 & 5,58 & 6,43 & 6,50 & 6,50 \\
\hline $\begin{array}{l}\text { Multimedia } \\
\text { Polska }\end{array}$ & 23.08 .2011 & 9,70 & 9,45 & 9,35 & 9,70 & nd. \\
\hline Ruch & 20.10 .2010 & 10,70 & 9,59 & 10,48 & 10,70 & 10,70 \\
\hline $\begin{array}{l}\text { WOLA } \\
\text { INFO }\end{array}$ & 08.10 .2010 & 3,70 & 3,53 & 3,51 & 3,70 & 3,70 \\
\hline $\begin{array}{c}\text { DZ Bank } \\
\text { Polska }\end{array}$ & 23.09 .2010 & 18,68 & 18,68 & 18,32 & nd. & nd. \\
\hline Nepentes & 13.09 .2010 & 28,00 & 27,76 & 27,64 & 28,00 & 28,00 \\
\hline $\begin{array}{l}\text { NKT Cab- } \\
\text { les (Kable) }\end{array}$ & 30.08 .2010 & 29,00 & 28,90 & 27,51 & 29,00 & 29,00 \\
\hline Teta & 30.07 .2010 & 14,00 & b.d. & b.d. & 14,00 & 14,00 \\
\hline
\end{tabular}


Tab. 3 (cd.)

\begin{tabular}{|c|c|c|c|c|c|c|}
\hline 1 & 2 & 3 & 4 & 5 & 6 & 7 \\
\hline WSIP & 30.04 .2010 & 17,15 & 16,67 & 16,84 & 17,15 & 17,15 \\
\hline $\begin{array}{c}\text { Optopol } \\
\text { Technology }\end{array}$ & 23.03 .2010 & 20,00 & 16,67 & 19,75 & 20,00 & 20,00 \\
\hline HTL-Strefa & 22.02 .2010 & 13,71 & 13,08 & 13,54 & 13,71 & 13,71 \\
\hline Bankier.pl & 29.01 .2010 & 9,00 & 8,84 & 8,81 & 9,00 & 9,00 \\
\hline
\end{tabular}

Objaśnienia do tabeli:

Cena 1 - cena przymusowego wykupu akcji;

Cena 2 - średnia cena rynkowa z okresu 6 miesięcy poprzedzających wezwanie;

Cena 3 - średnia cena rynkowa z okresu 3 miesięcy obrotu na rynku regulowanym poprzedzających wezwanie;

Cena 4 - najwyższa cena, jaką podmiot wzywający do sprzedaży zapłacił za te akcje w ciągu ostatnich 12 miesięcy przed wezwaniem;

Cena 5 - cena w wezwaniu, które doprowadziło do przekroczenia progu 90\% ogólnej liczby głosów w spółce;

b.d. - brak danych, dwie spółki w wezwaniach nie podały Ceny 1 i 2, gdyż te ceny były niższe niż Cena 4 i 5;

nd. - nie dotyczy.

Źródło: Opracowanie własne na podstawie bazy danych GPW.

Uzupełnieniem analizy danych zawartych w tabeli 3 jest tabela 4, w której są ukazane różnice pomiędzy ceną przymusowego wykupu akcji a minimalnymi cenami określonymi przez przepisy prawne.

Tabela 4

Różnice pomiędzy ceną przymusowego wykupu akcji a minimalnymi cenami określonymi przez przepisy prawne

\begin{tabular}{|c|c|c|c|c|c|c|c|c|}
\hline \multirow{2}{*}{ Spółka } & \multicolumn{9}{|c|}{ Różnica między Ceną 1 a: } \\
\cline { 2 - 9 } & \multicolumn{2}{|c|}{ Ceną 2 } & \multicolumn{2}{c|}{ Ceną 3 } & \multicolumn{2}{c|}{ Ceną 4 } & \multicolumn{2}{c|}{ Ceną 5 } \\
\cline { 2 - 9 } & zł & $\%$ & zł & $\%$ & zł & $\%$ & zł & $\%$ \\
\hline 1 & 2 & 3 & 4 & 5 & 6 & 7 & 8 & 9 \\
\hline $\begin{array}{c}\text { PANI } \\
\text { TERESA- } \\
\text { MEDICA }\end{array}$ & 0,4 & 2,66 & 0,23 & 1,51 & 0,00 & 0,00 & 0,00 & 0,00 \\
\hline $\begin{array}{c}\text { Infovide- } \\
\text { Matrix }\end{array}$ & 1,66 & 38,16 & 0,25 & 4,34 & 0,00 & 0,00 & 0,00 & 0,00 \\
\hline VARIANT & 0,02 & 1,21 & 0,02 & 1,21 & - & - & - & - \\
\hline KOFOLA & 13,03 & 29,63 & 1,75 & 3,17 & 0,00 & 0,00 & - & - \\
\hline ECARD & 1,09 & 37,46 & 0,42 & 11,73 & 0,00 & 0,00 & - & - \\
\hline
\end{tabular}




\begin{tabular}{|c|c|c|c|c|c|c|c|c|}
\hline 1 & 2 & 3 & 4 & 5 & 6 & 7 & 8 & 9 \\
\hline TVN & 1,35 & 7,24 & 0,29 & 1,47 & 0,00 & 0,00 & 0,00 & 0,00 \\
\hline Bipromet & 1,00 & 18,90 & 0,31 & 5,18 & 0,00 & 0,00 & 0,00 & 0,00 \\
\hline BGŻ & 7,40 & 10,13 & 6,74 & 9,14 & 0,00 & 0,00 & 0,00 & 0,00 \\
\hline $\begin{array}{c}\text { ZPC } \\
\text { Mieszko }\end{array}$ & 0,35 & 9,62 & 0,20 & 5,28 & 0,00 & 0,00 & 0,00 & 0,00 \\
\hline Bakalland & 0,24 & 9,37 & 0,03 & 1,08 & 0,00 & 0,00 & 0,00 & 0,00 \\
\hline Nordea Bank & 1,14 & 2,43 & 0,76 & 1,61 & 0,00 & 0,00 & 0,00 & 0,00 \\
\hline $\begin{array}{l}\text { Armatura } \\
\text { Kraków }\end{array}$ & - & - & - & - & 0,00 & 0,00 & 0,00 & 0,00 \\
\hline Barlinek & 0,05 & 4,00 & 0,02 & 1,56 & 0,00 & 0,00 & 0,00 & 0,00 \\
\hline POL-AQUA & 0,45 & 12,97 & 0,09 & 2,35 & 0,00 & 0,00 & 0,00 & 0,00 \\
\hline Zelmer & 2,16 & 5,71 & 0,70 & 1,78 & 0,00 & 0,00 & 0,00 & 0,00 \\
\hline $\begin{array}{l}\text { POLLENA- } \\
\text { EWA }\end{array}$ & 0,33 & 3,45 & 0,19 & 1,96 & 0,00 & 0,00 & 0,00 & 0,00 \\
\hline $\begin{array}{l}\text { Centrum } \\
\text { Klima }\end{array}$ & 1,69 & 13,19 & 0,22 & 1,54 & 0,00 & 0,00 & 0,00 & 0,00 \\
\hline TU Europa & 3,75 & 1,98 & 3,11 & 1,64 & 0,00 & 0,00 & 0,00 & 0,00 \\
\hline $\begin{array}{c}\text { Mondi } \\
\text { Świecie }\end{array}$ & 6,89 & 10,58 & 1,09 & 1,54 & 0,00 & 0,00 & 0,00 & 0,00 \\
\hline Elstar Oil & 0,92 & 16,49 & 0,07 & 1,09 & 0,00 & 0,00 & 0,00 & 0,00 \\
\hline $\begin{array}{l}\text { Multimedia } \\
\text { Polska }\end{array}$ & 0,25 & 2,65 & 0,35 & 3,74 & 0,00 & 0,00 & - & - \\
\hline Ruch & 1,11 & 11,57 & 0,22 & 2,10 & 0,00 & 0,00 & 0,00 & 0,00 \\
\hline $\begin{array}{l}\text { WOLA } \\
\text { INFO }\end{array}$ & 0,17 & 4,82 & 0,19 & 5,41 & 0,00 & 0,00 & 0,00 & 0,00 \\
\hline $\begin{array}{c}\text { DZ Bank } \\
\text { Polska }\end{array}$ & 0,00 & 0,00 & 0,36 & 1,97 & - & - & - & - \\
\hline Nepentes & 0,24 & 0,86 & 0,36 & 1,30 & 0,00 & 0,00 & 0,00 & 0,00 \\
\hline $\begin{array}{c}\text { NKT Cables } \\
\text { (Kable) }\end{array}$ & 0,10 & 0,35 & 1,49 & 5,42 & 0,00 & 0,00 & 0,00 & 0,00 \\
\hline Teta & - & - & - & - & 0,00 & 0,00 & 0,00 & 0,00 \\
\hline WSIP & 0,48 & 2,88 & 0,31 & 1,84 & 0,00 & 0,00 & 0,00 & 0,00 \\
\hline $\begin{array}{c}\text { Optopol } \\
\text { Technology }\end{array}$ & 3,33 & 19,98 & 0,25 & 1,27 & 0,00 & 0,00 & 0,00 & 0,00 \\
\hline HTL-Strefa & 0,63 & 4,82 & 0,17 & 1,26 & 0,00 & 0,00 & 0,00 & 0,00 \\
\hline Bankier.pl & 0,16 & 1,81 & 0,19 & 2,16 & 0,00 & 0,00 & 0,00 & 0,00 \\
\hline
\end{tabular}

Objaśnienia do tabeli: takie jak w tabeli 3.

Źródło: Opracowanie własne na podstawie bazy danych GPW. 
Na podstawie analizy danych zwartych w tabelach 3 i 4 okazuje się, że podmiot wzywający nie zapłacił więcej niż musiał. W każdym z analizowanych przypadków cena przymusowego wykupu akcji była równa najwyższej spośród określnych w ustawie cen minimalnych. W prawie wszystkich przypadkach była to cena, po jakiej akcjonariusz większościowy kupował akcje w ramach wezwania na sprzedaż $100 \%$ akcji spółki, które poprzedzało przymusowy wykup akcji.

Druga część badań miała za cel analogiczną analizę, jednak w odniesieniu do wezwań poprzedzających squeeze-out. W większości przypadków przymusowy wykup akcji był poprzedzony wezwaniem do sprzedaży 100\% akcji spółki. Tutaj również przepisy prawne określają minimalną cenę, po jakiej można dokonać takiego wezwania. Są one określone we wspomnianym już art. 79, ust. 1-3 ustawy o ofercie publicznej.

Kolejne dwie tabele ukazują, jak kształtowały się te ceny w 31 analizowanych przypadkach. Tabela 5 przedstawia ceny w wezwaniach na sprzedaż $100 \%$ akacji, a tabela 6 zawiera różnice pomiędzy ceną w wezwaniu a minimalnymi cenami wynikającymi z przepisów prawnych. W pięciu spośród analizowanych 31 przypadków przymusowy wykup akcji nie był poprzedzony wezwaniem na sprzedaż $100 \%$ akcji.

Tabela 5

Ceny (w zł) w wezwaniach na sprzedaż $100 \%$ akcji

\begin{tabular}{|c|c|c|c|c|c|}
\hline Spółka & $\begin{array}{c}\text { Data } \\
\text { wezwania }\end{array}$ & Cena 6 & Cena 2 & Cena 3 & Cena 4 \\
\hline 1 & 2 & 3 & 4 & 5 & 6 \\
\hline $\begin{array}{c}\text { PANI } \\
\text { TERESA- } \\
\text { MEDICA }\end{array}$ & 10.09 .2015 & 15,45 & 15,45 & 14,84 & nd. \\
\hline $\begin{array}{c}\text { Infovide- } \\
\text { Matrix }\end{array}$ & 23.09 .2015 & 6,01 & 3,64 & 2,97 & nd. \\
\hline VARIANT & nd. & nd. & nd. & nd. & nd. \\
\hline KOFOLA & nd. & nd. & nd. & nd. & nd. \\
\hline ECARD & nd. & nd. & nd. & nd. & nd. \\
\hline TVN & 06.07 .2015 & 20,00 & 17,71 & 17,83 & nd. \\
\hline Bipromet & 29.01 .2015 & 6,29 & 3,73 & 3,48 & nd. \\
\hline BGŻ & 25.08 .2014 & 80,47 & 69,88 & 69,65 & nd. \\
\hline $\begin{array}{c}\text { ZPC } \\
\text { Mieszko }\end{array}$ & 29.08 .2014 & 3,99 & 3,61 & 3,47 & 3,50 \\
\hline
\end{tabular}




\begin{tabular}{|c|c|c|c|c|c|}
\hline 1 & 2 & 3 & 4 & 5 & 6 \\
\hline Bakalland & 11.08 .2014 & 2,80 & 2,23 & 2,34 & nd. \\
\hline Nordea Bank & 03.12 .2013 & 47,99 & 46,25 & 46,97 & nd. \\
\hline $\begin{array}{l}\text { Armatura } \\
\text { Kraków }\end{array}$ & 30.08 .2013 & 1,70 & 1,50 & 1,60 & 1,70 \\
\hline Barlinek & 03.10 .2013 & 1,30 & 1,08 & 1,21 & nd. \\
\hline POL-AQUA & 23.07 .2013 & 3,92 & 3,92 & 2,93 & nd. \\
\hline Zelmer & 14.11 .2012 & 40,00 & 29,06 & 30,36 & nd. \\
\hline $\begin{array}{l}\text { POLLENA- } \\
\text { EWA }\end{array}$ & 21.08 .2012 & 9,90 & 9,22 & 9,82 & 9,90 \\
\hline $\begin{array}{l}\text { Centrum } \\
\text { Klima }\end{array}$ & 02.05 .2012 & 14,50 & 10,44 & 11,58 & 14,50 \\
\hline TU Europa & 14.12 .2011 & 193,00 & 166,99 & 155,37 & nd. \\
\hline $\begin{array}{c}\text { Mondi } \\
\text { Świecie }\end{array}$ & 16.01 .2012 & 72,00 & 66,26 & 59,71 & nd. \\
\hline Elstar Oil & 16.08 .2011 & 6,50 & 4,70 & 4,51 & nd. \\
\hline $\begin{array}{l}\text { Multimedia } \\
\text { Polska }\end{array}$ & nd. & nd. & nd. & nd. & nd. \\
\hline Ruch & 23.07 .2010 & 10,70 & 8,68 & 8,66 & nd. \\
\hline $\begin{array}{l}\text { WOLA } \\
\text { INFO }\end{array}$ & 17.05 .2010 & 3,70 & 3,68 & 3,48 & nd. \\
\hline $\begin{array}{l}\text { DZ Bank } \\
\text { Polska }\end{array}$ & nd. & nd. & nd. & nd. & nd. \\
\hline Nepentes & 19.05 .2010 & 28,00 & 26,39 & 27,92 & nd. \\
\hline $\begin{array}{c}\text { NKT Cables } \\
\text { (Kable) }\end{array}$ & 11.09 .2009 & 29,00 & 23,01 & 24,24 & nd. \\
\hline Teta & 18.06 .2010 & 14,00 & 11,60 & 11,38 & nd. \\
\hline WSIP & 06.11 .2009 & 17,15 & 15,48 & 16,07 & nd. \\
\hline $\begin{array}{l}\text { Optopol } \\
\text { Technology }\end{array}$ & 22.12 .2009 & 20,00 & 15,56 & 14,09 & nd. \\
\hline HTL-Strefa & 08.10 .2009 & 13,71 & 12,17 & 12,33 & nd. \\
\hline Bankier.pl & 24.11.2009 & 9,00 & 8,74 & b.d. & 9,00 \\
\hline
\end{tabular}

Objaśnienia do tabeli: Cena 6 - cena w wezwaniu na $100 \%$ akcji, pozostałe oznaczenia takie jak w tabeli 3 .

Źródło: Opracowanie własne na podstawie bazy danych GPW. 
Tabela 6

Różnice pomiędzy ceną w wezwaniu na 100\% akcji a minimalnymi cenami określonymi przez przepisy prawne

\begin{tabular}{|c|c|c|c|c|c|c|}
\hline \multirow{3}{*}{ Spółka } & \multicolumn{6}{|c|}{ Różnica między Ceną 6 a: } \\
\hline & \multicolumn{2}{|c|}{ Ceną 2} & \multicolumn{2}{|c|}{ Ceną 3} & \multicolumn{2}{|c|}{ Ceną 4} \\
\hline & $\mathrm{zł}$ & $\%$ & $\mathrm{zł}$ & $\%$ & $\mathrm{z} 1$ & $\%$ \\
\hline 1 & 2 & 3 & 4 & 5 & 6 & 7 \\
\hline $\begin{array}{c}\text { PANI } \\
\text { TERESA- } \\
\text {-MEDICA }\end{array}$ & 0,00 & 0,00 & 0,61 & 3,95 & nd. & nd. \\
\hline $\begin{array}{l}\text { Infovide- } \\
\text {-Matrix }\end{array}$ & 2,37 & 39,43 & 3,04 & 50,58 & nd. & nd. \\
\hline VARIANT & nd. & nd. & nd. & nd. & nd. & nd. \\
\hline KOFOLA & nd. & nd. & nd. & nd. & nd. & nd. \\
\hline ECARD & nd. & nd. & nd. & nd. & nd. & nd. \\
\hline TVN & 2,29 & 11,45 & 2,17 & 10,85 & nd. & nd. \\
\hline Bipromet & 2,56 & 40,70 & 2,81 & 44,67 & nd. & nd. \\
\hline BGŻ & 10,59 & 13,16 & 10,82 & 13,45 & nd. & nd. \\
\hline $\begin{array}{l}\text { ZPC Miesz- } \\
\text { ko }\end{array}$ & 0,38 & 9,52 & 0,52 & 13,03 & 0,49 & 12,28 \\
\hline Bakalland & 0,57 & 20,36 & 0,46 & 16,43 & nd. & nd. \\
\hline $\begin{array}{c}\text { Nordea } \\
\text { Bank }\end{array}$ & 1,74 & 3,63 & 1,02 & 2,13 & nd. & nd. \\
\hline $\begin{array}{c}\text { Armatura } \\
\text { Kraków }\end{array}$ & 0,20 & 11,76 & 0,10 & 5,88 & 0,00 & 0,00 \\
\hline Barlinek & 0,22 & 16,92 & 0,09 & 6,92 & nd. & nd. \\
\hline POL-AQUA & 0,00 & 0,00 & 0,99 & 25,26 & nd. & nd. \\
\hline Zelmer & 10,94 & 27,35 & 9,64 & 24,10 & nd. & nd. \\
\hline $\begin{array}{l}\text { POLLENA- } \\
\text {-EWA }\end{array}$ & 0,68 & 6,87 & 0,08 & 0,81 & 0,00 & 0,00 \\
\hline $\begin{array}{c}\text { Centrum } \\
\text { Klima }\end{array}$ & 4,06 & 28,00 & 2,92 & 20,14 & 0,00 & 0,00 \\
\hline TU Europa & 26,01 & 13,48 & 37,63 & 19,50 & nd. & nd. \\
\hline $\begin{array}{c}\text { Mondi } \\
\text { Świecie }\end{array}$ & 5,74 & 7,97 & 12,29 & 17,07 & nd. & nd. \\
\hline Elstar Oil & 1,80 & 27,68 & 1,99 & 30,62 & nd. & nd. \\
\hline $\begin{array}{l}\text { Multimedia } \\
\text { Polska }\end{array}$ & nd. & nd. & nd. & nd. & nd. & nd. \\
\hline
\end{tabular}




\begin{tabular}{|c|c|c|c|c|c|c|}
\hline 1 & 2 & 3 & 4 & 5 & 6 & 7 \\
\hline Ruch & 2,02 & 18,88 & 2,04 & 19,07 & nd. & nd. \\
\hline $\begin{array}{c}\text { WOLA } \\
\text { INFO }\end{array}$ & 0,02 & 0,54 & 0,22 & 5,95 & nd. & nd. \\
\hline $\begin{array}{c}\text { DZ Bank } \\
\text { Polska }\end{array}$ & nd. & nd. & nd. & nd. & nd. & nd. \\
\hline Nepentes & 1,61 & 5,75 & 0,08 & 0,29 & nd. & nd. \\
\hline $\begin{array}{c}\text { NKT Cables } \\
\text { (Kable) }\end{array}$ & 5,99 & 20,66 & 4,76 & 16,41 & nd. & nd. \\
\hline Teta & 2,40 & 17,14 & 2,62 & 18,71 & nd. & nd. \\
\hline WSIP & 1,67 & 9,74 & 1,08 & 6,30 & nd. & nd. \\
\hline $\begin{array}{c}\text { Optopol } \\
\text { Technology }\end{array}$ & 4,44 & 22,20 & 5,91 & 29,55 & nd. & nd. \\
\hline HTL-Strefa & 1,54 & 11,23 & 1,38 & 10,07 & nd. & nd. \\
\hline Bankier.pl & 0,26 & 2,89 & - & - & 0,00 & 0,00 \\
\hline
\end{tabular}

Objaśnienia do tabeli: takie jak w tabeli 5.

Źródło: Opracowanie własne na podstawie bazy danych GPW.

Na podstawie analizy danych zawartych w tabelach 5 i 6 widać, że podmiot wyzywający oferował premię akcjonariuszom spółki, od których chciał odkupić akcje. Wysokość tej premii była zróżnicowana. Największe korzyści mogli osiągnąć akcjonariusze spółki Bipromet i Infovide-Matrix. KGHM dokonujący przejęcia Biprometu zaproponował cenę w wezwaniu o ponad $40 \%$ wyższą niż określona ustawowo cena minimalna. Zaś Asseco Poland, mając zamiar przejęcia spółki Infovide-Matrix, zaproponował cenę wyższą o 40-50\%. Były to jednak wyjątki. Zazwyczaj podmioty dokonujące wykupu dawały premię nie większą niż 30\%. Przeciętnie cena zaproponowana w wezwaniu była wyższa o 16,47\% od średniej ceny rynkowej z okresu 3 miesięcy przy odchyleniu standardowym 12,72 i średnio o 14,90\% wyższa od średniej ceny rynkowej z okresu 6 miesięcy przy odchyleniu standardowym 11,16 . W połowie badanych przypadków cena w wezwaniu była niższa o mniej niż $16,41 \%$ od średniej ceny rynkowej z ostatnich 3 miesięcy, a w połowie była wyższa. W przypadku średniej ceny rynkowej z ostatnich 6 miesięcy wartość mediany wynosiła 12,46\%. W jednej czwartej przypadków różnica między ceną w wezwaniu a średnią ceną rynkową z ostatnich 3 miesięcy była mniejsza niż 6,30\%, zaś w jednej czwartej przypadków była większa niż $20,14 \%$. W przypadku różnic między ceną w wezwaniu a średnią ceną rynkową z ostatnich 6 miesięcy wartości te wynosiły odpowiednio 7,15\% i 20,56\%. Szczegółowe dane dotyczące rozkładu uzyskanych wyników znajdują się w tabeli 7. Wszystkie rozkłady są prawostronnie skośne (dodatnie wartości współczynnika skośności). 
Statystyka różnic cen w wezwaniach na sprzedaż 100\% akcji

\begin{tabular}{|c|c|c|}
\cline { 2 - 3 } \multicolumn{1}{c|}{} & \multicolumn{2}{c|}{ Różnice między Ceną 6 a: } \\
\cline { 2 - 3 } \multicolumn{1}{c|}{} & Ceną 2 $(\mathrm{w} \%)$ & Ceną 3 $(\mathrm{w} \%)$ \\
\hline Maksimum & 40,70 & 50,58 \\
\hline Minimum & 0,00 & 0,29 \\
\hline Średnia & 14,90 & 16,47 \\
\hline Odchylenie standardowe & 11,15757111 & 12,71626691 \\
\hline Mediana & 12,46 & 16,41 \\
\hline Pierwszy kwartyl & 7,145 & 6,3 \\
\hline Trzeci kwartyl & 20,585 & 20,14 \\
\hline Współczynnik skośności & 0,713122794 & 1,047596127 \\
\hline
\end{tabular}

Objaśnienia do tabeli: takie jak w tabeli 5.

Źródło: Opracowanie własne.

W tabeli 8 zaprezentowano zestawienie ukazujące, jak często pojawiały się dane wielkości różnic. Porównanie ceny w wezwaniu ze średnią ceną rynkową z ostatnich 6 miesięcy pokazuję, że w dziesięciu przypadkach różnica znajdowała się w przedziale od 5 do $15 \%$. Analogiczne porównania ze średnią ceną rynkową z ostatnich 3 miesięcy wskazuje, że najczęściej różnica zawierała się w przedziale od 15 do $20 \%$ (w sześciu przypadkach).

Tabela 8

Liczba przypadków występowania określonych wielkości analizowanych różnic

\begin{tabular}{|c|c|c|}
\hline \multirow{2}{*}{ Wielkość różnic $(\mathrm{w} \%)$} & \multicolumn{2}{|c|}{ Liczba przypadków } \\
\cline { 2 - 3 } & Różnice między ceną 6 a ceną 2 & Różnice między ceną 6 a ceną 3 \\
\hline$>30$ & 2 & 3 \\
\hline $25-30$ & 3 & 2 \\
\hline $20-25$ & 3 & 2 \\
\hline $15-20$ & 3 & 4 \\
\hline $10-15$ & 5 & 4 \\
\hline $5-10$ & 5 & 4 \\
\hline $0-5$ & 3 & \\
\hline
\end{tabular}

Objaśnienia do tabeli: takie jak w tabeli 5.

Źródło: Opracowanie własne. 


\section{ZAKOŃCZENIE}

Przymusowy wykup akcji pozwala dominującemu akcjonariuszowi lub akcjonariuszom ,pozbyć” się ze spółki mniejszościowych akcjonariuszy. Przepisy regulujące squeeze-out z jednej strony dbają o interesy większościowych udziałowców, a z drugiej strony chronią drobnych akcjonariuszy (w szczególności chodzi tu o przepisy regulujące cenę, po jakiej jest dokonywany przymusowy wykup akcji). W okresie od 2005 roku, czyli od wejścia w życie ustawy regulującej tę kwestię, do końca roku 2015 przeprowadzono 48 przymusowych wykupów akcji spółek notowanych na Giełdzie Papierów Wartościowych w Warszawie.

Celem niniejszego opracowania była analiza kształtowania się cen przymusowych wykupów akcji na GPW w Warszawie i znalezienie odpowiedzi na pytanie, czy dominujący akcjonariusz (bądź akcjonariusze), dokonując przymusowego wykupu akcji, byli skłonni zapłacić drobnym akcjonariuszom więcej niż cena minimalna określona w przepisach prawnych. Dodatkowo przeanalizowano ceny w wezwaniach poprzedzających przymusowy wykup akcji, stawiając analogiczne pytanie, czy drobni akcjonariusze otrzymali propozycje ceny wyższej niż minimalna cena wymagana przepisami prawnymi. Postawione zostały dwie hipotezy badawcze powiązane $\mathrm{z}$ wyznaczonymi celami. Ponadto w przypadku pojawienia się nadwyżki zaproponowanej ceny ponad minimalną cenę wymaganą przepisami, zbadano jej wysokość. Szczegółowej analizie poddano ceny w 31 wezwaniach squeeze-out przeprowadzanych w latach 2010-2015.

Przeprowadzona analiza ujawniła, że dominujący akcjonariusz dokonujący przymusowego wykupu nie płacił więcej niż musiał. W każdym z analizowanych przypadków cena przymusowego wykupu akcji była równa najwyższej spośród określnych w ustawie cen minimalnych. W prawie wszystkich przypadkach była to cena, po jakiej akcjonariusz większościowy kupował akcje w ramach wezwania na sprzedaż 100\% akcji spółki, które poprzedzało przymusowy wykup akcji. Taka sytuacja ma jednak swoje racjonalne uzasadnienie. Zgodnie z art. 74, ust. 3 ustawy o ofercie publicznej akcjonariusz, który w ciągu 6 miesięcy po przeprowadzeniu wezwania nabywa akcje po cenie wyższej niż cena określona w tym wezwaniu, ma obowiązek w ciągu miesiąca od tej transakcji zapłacić różnicę wszystkim osobom, które zbyły akcje w ramach tego wezwania. ${ }^{6}$ Artykuł ustawy nie wymienia dosłownie sytuacji związanej z przymusowym wykupem akcji, jednak przepis ten dotyczy również tych przypadków. Potwierdza to stanowisko Urzędu Komisji Nadzoru Finansowego (UKNF) z maja 2007 roku, w którym dokonana jest interpretacja tego artykułu (Stanowisko... 2007). Zgodnie z interpretacją UKNF, jeśli po wezwaniu na 100\% akcji, akcjonariusz nabyłby akcje po cenie wyższej niż w wezwaniu, musiałby dopłacić różnicę cen wszystkim

\footnotetext{
${ }^{6}$ Ustawa dopuszcza pewne wyjątki, ale ogólna reguła nakazuje dopłacić różnicę.
} 
podmiotom, od których nabył akcje po niższej cenie w ramach wezwania. Innymi słowy, jeśli zapłaciłby więcej w ramach przymusowego wykupu, to musiałby dopłacić różnice wszystkim, od których kupił akcje wcześniej w ramach wezwania na $100 \%$ akcji. Takie działanie byłby nieracjonalne ekonomicznie, gdyż naraziłoby dany podmiot na dodatkowe koszty. Żaden z podmiotów przeprowadzających przymusowy wykup nie skusił na ten wariant. Na tej podstawie hipotezę pierwszą należy zweryfikować negatywnie.

Dokonano również analizy cen w wezwaniach na sprzedaż $100 \%$ akcji poprzedzających przymusowy wykup akcji. Taka sytuacja miał miejsce w 26 spośród 31 analizowanych przypadków. Przeprowadzone analizy ujawniają, że większościowy akcjonariusz oferował pewną premię dotychczasowym udziałowcom spółki. Wielkość tej premii była zróżnicowana. W jednym przypadku cena w wezwaniu przekraczała ustawowo określoną cenę minimalną o ponad $50 \%$. W większości przypadków premia nie przekraczała jednak $30 \%$. Średnio była na poziomie około $15 \%$. Uzyskane wyniki pozwalają na pozytywną weryfikację hipotezy drugiej.

$\mathrm{Na}$ podstawie przeprowadzonych badań można wysnuć pewne wnioski. W sytuacji, gdy dominujący akcjonariusz ${ }^{7}$ zamierza nabyć $100 \%$ akcji spółki giełdowej, wykorzystując rozwiązanie przymusowego wykupu akcji, inwestorzy mniejszościowi nie mogą liczyć na cenę wyższą niż minimalna cena określona w ustawie o ofercie publicznej. Taka premia ponad cenę ustawową pojawić się może w wezwaniach na sprzedaż 100\% akcji spółki, które poprzedzają squeeze-out. Wysokość tej premii nie jest jednak w żaden sposób gwarantowana i zależy od ,dobrej woli” podmiotu nabywającego akcje. Akcjonariusze mniejszościowi, którzy uważają, że cena zaoferowana w wezwaniu jest zbyt niska, mogą je zignorować i nie pozbywać się swoich akcji. Dominujący akcjonariusz musi wówczas podnieść zaproponowaną cenę, w przeciwnym razie musi się liczyć z tym, że nie uda mu się nabyć planowanego pakietu akcji. Jest to szczególnie istotne w kontekście warunku umożliwiającego skorzystanie z procedury przymusowego wykupu akcji. Akcjonariusz lub akcjonariusze większościowi mogą przeprowadzić squeeze-out w spółce publicznej, jeśli dysponują udziałem $90 \%$ ogólnej liczby głosów w spółce. W sytuacji, gdy próg ten zostanie przekroczony i podmiot dominujący decyduje się na przymusowy wykup, akcjonariusze mniejszościowi nie mają już zbyt wiele do powiedzenia, gdyż transakcja ta jest przeprowadzana bez ich zgody i po cenie narzuconej przez wykupującego.

${ }^{7}$ Ewentualnie podmiot, który nie jest akcjonariuszem spółki, lecz zamierza nabyć większościowy pakiet akcji. Tak było w przypadku spółki Zelmer, niemiecki koncern BSH nie był akcjonariuszem spółki, gdy ogłaszał wezwanie na sprzedaż $100 \%$ akcji, poprzedzające przymusowy wykup. 


\section{BIBLIOGRAFIA}

Assant O., Kanovitch B. (2005), Simplifying French public-to-private deals, "International Financial Law Review", vol. 24, no. 6, p. 25-27.

Birkner A., Hasenauer C. (2007), Squeeze-out options defined, "International Financial Law Review" Mergers \& Acquisitions, vol. 26, p. 13-15.

Cafritz E. (2005), France set to expand use of fairness opinions, "International Financial Law Review", vol. 24, no. 5, p. 17-19.

Fujiwara S., Tsujikawa M. (2008), New procedures for fair MBOs, "International Financial Law Review" Guide to Japan, vol. 27, p. 27-32.

Gencs V. (2004), Minority shareholders' rights in squeeze-outs, "International Financial Law Review", vol. 23, no. 12 , p. 52-54.

Horbach M., Koch S. (2006), Towards a faster, easier squeeze-out, "International Financial Law Review", vol. 25, no. 5, p. 24-25.

Marc P., Lisková V. (2006), Squeeze-out regime, "International Financial Law Review”, vol. 25, no. 11, p. $70-71$.

Nicholls C.C. (2006), Lock-Ups, Squeeze-Outs, and Canadian Takeover Bid Law: A Curious Interplay of Public and Private Interests, "McGill Law Journal", vol. 51, no. 2, p. 407-427.

Nanyista L., Hetényi K. (2007), Hungary clarifies squeeze-out rules, "International Financial Law Review" Mergers \& Acquisitions, vol. 26, p. 37-39.

Nowak D. (2006), Squeeze-out a sell out right - porównanie, „Edukacja Prawnicza”, nr 6(81), s. $25-27$.

Pinior P., Wyrzykowski W. (2008), Przymusowy wykup i odkup akcji w spółkach publicznych i niepublicznych, „Prawo Spółek” e-wydanie, nr 9, s. 9.

Puchalski A. (2015), Polska regulacja przymusowego wykupu akcji w spótkach publicznych na tle prawa unijnego, „Przegląd Prawa Handlowego” nr 1, s. 45-53.

Rampos D. (2007), Squeeze-outs arrive, "International Financial Law Review", vol. 26, no. 3, p. $30-31$.

Regner W.D. (2006), Going private in the US, “International Financial Law Review" Supplement, vol. 25 , p. $158-160$.

Rusek J., Hajdecki P. (2008), Squeeze out, czyli wyciskanie akcjonariusza mniejszościowego, „Nasz Rynek Kapitałowy", nr 5, s. 75-77.

Siska K., Tadlánková L. (2007), Shareholders feel the squeeze, "International Financial Law Review" Mergers \& Acquisitions, vol. 26, p. 75-77.

Stanowisko dotyczące art. 74, art 83 i art 79 ustawy o ofercie publicznej i warunkach wprowadzania instrumentów finansowych do zorganizowanego systemu obrotu oraz spółkach publicznych (maj 2007 r.), syg. DPP-P-007/2007, http://www.knf.gov.pl/Images/art_74_art83_i_art79_ ustawy_o_ofercie_tcm75-1830.pdf, (dostęp: 29.06.2015).

Ustawa z dnia 29 lipca 2005 r. o ofercie publicznej i warunkach wprowadzania instrumentów finansowych do zorganizowanego systemu obrotu oraz o spółkach publicznych (Dz.U. 2005 nr 184 poz. 1539 z późn. zm.).

Walasek W. (2008), Polska regulacja przymusowego wykupu akcji drobnych akcjonariuszy spótek publicznych (squeeze out), „Przegląd Prawa Handlowego” nr 2, s. 53-58.

Woźniak R. (2014), Zasady ustalania ceny w przymusowym wykupie w przypadku spótki publicznej, „Przegląd Prawa Handlowego" nr 7, s. 50-54.

Wyszogrodzka E. (2006), Dostosowanie polskiej procedury przymusowego wykupu akcji akcjonariuszy mniejszościowych (squeeze out) do wymogów europejskich, „Radca Prawny” nr 2, s. $51-62$. 
Van der Elst C., Van den Steen L. (2009), Balancing the Interests of Minority and Majority Shareholders: A Comparative Analysis of Squeeze-out and Sell-out Rights, "European Company \& Financial Law Review" vol. 6, no. 4, p. 391-439.

Zarzecki D., Grudziński M. (2011), Wartość godziwa jako standard wartości w wycenach sporzadzonych w sytuacji przymusowego wykupu akcji, „Zeszyty Naukowe Uniwersytetu Szczecińskiego. Finanse. Rynki Finansowe. Ubezpieczenia", nr 37, s. 661-676.

Baza danych GPW, http://www.gpwinfostrefa.pl/GPWIS2/pl/index/, (dostęp: 20.01.2016).

\title{
Katarzyna Królik-Kottunik
}

\section{ANALYSIS OF PRICES IN SQUEEZE-OUTS AND CALLS PRECEDING THEM ON WARSAW STOCK EXCHANGE}

\begin{abstract}
The functioning of the stock market, as a regulated market, is normed in the law. In most cases, these provisions are intended to protect the non-professional market participants, individual investors or minority shareholders. An example of such legislation is to set a minimum price at which it is carried out a squeeze-out. This provision is intended to ensure minority shareholders the appropriate price in return for the repurchased shares under conditions where their position has become essentially marginal. The aim of this paper is to analyze the prices in squeezeouts on the Warsaw Stock Exchange and in the calls preceding the squeeze-out.
\end{abstract}

Keywords: stock, squeeze-out, capital market. 